\title{
Productivity Measuring In The Czech Banking Industry
}

\author{
Dimitrios Angelidis, University of Macedonia, Greece \\ Katerina Lyroudi, (Email: lyroudi@uom.gr), University of Macedonia, Greece \\ Athanasios Koulakiotis, (Email: a_koulakiotis@hotmail.com), University of the Aegean, Greece
}

\begin{abstract}
In this paper we investigate the productivity of the Czech banking industry for the period 1996-2002. The non-parametric frontier method of data envelopment analysis (DEA) is used in order to estimate the Malmquist total factor productivity (TFP) change indices for 134 year-firm observations. Using the value added approach and calculating the geometric mean of the TFP, we find that the level of productivity of financial institutions meets a decline of 0.7\%. Moreover, the technical efficiency changes (TEC) is greater than unity, while the technological change (TC) is less than unity for the Czech banks during the period $1996-2002$.
\end{abstract}

\section{INTRODUCTION}

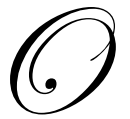

$\mathrm{n}$ the $16^{\text {th }}$ of April 2004 the European Union (EU) met a major expansion as ten new country-members entered the Union. Definitely, this was the most significant and impressive extension of the EU as it was the first time that such a number of countries jointed the EU at the same time. These countries in alphabetic order are: Cyprus, Czech Republic, Estonia, Hungary, Latvia, Lithuania, Malta, Poland, Slovenia and Slovakia. With the exception of Cyprus and Malta, the other eight new members were transitional economies, whereby the political structure and the economic framework had begun being reformed during the period before the entrance date and will continue afterwards, till they meet the EU standards for all its members. Hence, it is essential to study the performance of these countries in their new economic and financial environment.

The objective of this study is to investigate the performance of the Czech banking industry in terms of efficiency during the period just before the entrance date. Financial institutions may be considered as the cornerstone of any economic system, due to their magnitude. Therefore, a first step in investigating the level of effectiveness for the economy of a given country is to explore the performance of its financial institutions. Consequently, this study focuses on the banking system of a new country-member, the Czech Republic. The intention of this paper is to evaluate the level of productivity of the financial institutions of this particular country, before its entrance in the EU, during the period 1996 and 2002. These mainly new established banks could operate under the umbrella of protection of the national laws. Though, after the entrance of the country into the EU they have to operate in a global and highly competitive market.

As long as the level of productivity has an increasing trend, a positive omen for the future exists. If not, the financial institutions and accordingly the whole financial and economic system of the country are under the hazard of a potential economic depression and there is the need for rapid and precautionary measures to prevent this from happening.

The structure of this paper is as follows: Section 2 reviews the relative literature. Section 3 describes the methodology and the data. Section 4 presents and analyses the results and finally section 5 contains the summary and concluding remarks. 


\section{LITERATURE REVIEW}

A number of studies bring into light evidence of economies of scale and bank efficiency. Among others, Glass and McKillop (1991) investigated the efficiency of Irish banking for the period 1972 to 1990. According to their findings, there was no evidence of economies of scale. Moreover, whereas the banking sector was found to exhibit diseconomies of scope in earlier sub-periods of the sample, by the late 1980s a reversal had occurred and economies of scale pertained. Finally, the authors documented positive values of the coefficient for the non-neutral technical change, especially from 1984 and onwards.

Berg, Forsund and Jansen (1992), in a pioneer project, examined productivity growth during the deregulation of the Norwegian banking industry employing the Data Envelopment Analysis. They found productivity deterioration for the average bank prior to the deregulation, but rabid growth in productivity after the deregulation took place.

Elyasiani and Mehdian (1995) compared the efficiency performance of small and large US commercial banks in the pre-and post-deregulation eras. Their findings suggested that in the pre-deregulation environment small banks were more efficient than large banks. However, in the deregulated environment small and large banks were equally efficient.

In an attempt to estimate bank efficiency, Favero and Papi (1995) measured the technical and scale efficiencies of the Italian banking industry using 174 Italian banks in 1991. Efficiency (or inefficiency) was best explained by productivity specialization, size and to a lesser extent by location. They found a positive relationship between bank size and efficiency. The significance of location in explaining efficiency seemed to capture the lesser efficiency of the banks located in southern Italy.

Using the Malmquist index, Fukuyama (1995) investigated the nature and the extent of efficiency and productivity growth in Japanese banking. According to the empirical evidence, the values of Malmquist index in the period 1989-90 were greater than those in the period 1990-91. Meanwhile, improved productivity and innovation and deteriorated efficiency were, on average, evidenced for both periods.

Dietsch (1997) presented estimates of X-efficiencies and scale-efficiencies for French banks for the period 1988-1992. His estimations showed that average X-efficiencies of the French banks were in the range of $70 \%$ to $90 \%$. His results, also, confirmed the existence of economies of scale in the French banking industry.

Noulas (1997) employed the Malmquist index to investigate the productivity growth of the Greek banking industry for the years 1991 and 1992. His results indicated that although productivity had increased for state and private banks, the sources of this growth were different. State banks' productivity came from technological progress while private banks' productivity came from increased efficiency.

Jackson et al. (1998) analyzed productivity growth in Turkish commercial banking sector during the period 1992-1996. In general, Turkish commercial banking experienced productivity growth with the exception of 19931994. Among the three ownership types, private and foreign banks showed greater productivity growth compared to the state owned banks.

Based on the efficiency and productivity growth of banks, Worthington (1998) investigated the efficiency and the productivity growth of the deposit taking institutions in Australia. His results indicated that most building societies experienced productivity gain in the past years. This was largely the result of technological progress rather than efficiency improvement. That productivity growth that occurred due to an increase in efficiency over the period, tended to be the result of improvements in scale efficiency.

In a regional comparison of bank efficiency, Fernández et al. (2001) studied economic efficiency in 142 intermediaries from 18 countries over the period 1989-1998. They scheduled their sample into three different geographic areas: North America, Europe and Japan. Their estimates of efficiency scores showed large gains due primarily to growth in pure technical efficiency. Mean technical efficiency in European and Japanese banks has been 
significantly larger than in North American banks. Finally, the best managed commercial banks were the European ones, while Japanese banks were the most scale efficient.

More recent study by Caceres (2002) investigated productivity growth in the Chilean banking industry over the period 1989-1999. His results indicated that after a period of rapid productivity growth, the banking sector experienced lower and relatively stable rates of productivity change. Also, it was the small banks group with the greater number of inefficient banks. Overall, the average values of Malmquist index tended to be greater from 1996 onward and there were no large technical inefficiencies in the Chilean banking industry.

In addition, Darrat et al. (2002) examined productivity changes in Kuwait's banks. Their results suggested that the sources of inefficiency were both allocative (regulatory) as well as technical (managerial). Also, results from the Malmquist index revealed that there had been a substantial increase (about 28\%) in the productivity of Kuwait banks, which was mainly attributable to the technological improvement. Finally, small banks appeared to be more efficient than large banks.

Mörttinen (2002) computed labour productivity in banking sector, using Tornqvist indices for six countries (Finland, Sweden, United Kingdom, Italy, Germany and France) over a period varying from 11 to 20 years. According to her results, Finnish banking sector productivity had been improved via a substantial reduction in size of labour force, whereas output growth had been rather modest. Although in most of the countries the restructuring process had been less intense, most of the sectors studied had been improved in terms of overall output and labour productivity, especially, since the mid-1990s.

Moreover, Tortosa-Ausina et al. (2002) explored productivity growth and productive efficiency for Spanish savings banks over the period 1992-1998. Their results showed that productivity growth had occurred mainly due to improvement of production possibilities, implying that efficiency had remained fairly constant over time.

Finally, Reddy (2004) measured productivity growth of the Indian banking industry for the period from 1996 to 2002. He found that during this period, bank Total Factor Productivity (TFP) almost stagnated, while contribution of technological progress towards productivity declined. However, technical efficiency and scale efficiency had been improved for all banks. The highest TFP had been observed among public sector banks followed by old private banks. On the other hand, both new private banks and foreign banks recorded a decline in TFP growth.

\section{METHODOLOGY AND DATA}

\section{Methodology}

This section analyses the methodology, which is employed to measure the level of productivity of the banking industry of Czech Republic. In this study the data envelopment analysis (DEA) technique is employed to calculate the Malmquist indices of total factor productivity (TFP) change. DEA is a non-parametric approach of frontier estimation. The term DEA was invented by the paper of Charnes, Cooper and Rhodes (1978). These authors proposed a model, which had an input orientation and assumed constant returns to scale. The present paper follows the above model. Since then, a huge number of papers used and extended the DEA methodology. Tavares (2002) stated that until January of 2002 the DEA bibliography database consisted of 3,203 publications written by 2,152 distinct authors.

Malmquist TFP index calculates changes in total output relative to inputs. The idea developed by the Swedish statistician Malmquist (1953). The Malmquist TFP index is one of the most frequently used method to assess productivity change. As it is mentioned at section 2, the TFP index was initially introduced by the study of Berg, Forsund and Jansen (1992) in order to capture the productivity changes in the banking sector. Since, a great number of studies employed the Malmquist TFP index to measure productivity of financial institutions. 
The Malmquist TFP index calculates the change in productivity between two points by estimating the ratio of the distances of each point relative to a common technology. The Malmquist input oriented TFP change index between the base period $t$ and the following period $t+1$ is defined as:

$\mathrm{M}\left(\mathrm{y}_{\mathrm{t}}, \mathrm{x}_{\mathrm{t}}, \mathrm{y}_{\mathrm{t}+1}, \mathrm{x}_{\mathrm{t}+1}\right)=\left[\frac{d_{t+1}\left(Y_{t+1}, X_{t+1}\right)}{d_{t}\left(Y_{t}, X_{t}\right)} X \frac{d_{t}\left(Y_{t+1}, X_{t+1}\right)}{d_{t+1}\left(Y_{t+1}, X_{t+1}\right)}\right]^{1 / 2}$

As long as $\mathrm{M}$ is greater than unity a positive TFP growth from the period $t$ to period $t+1$ has taken place. On the antipode, a value of M less than one indicates a TFP's fall. Equation (1) is the geometric mean of two TFP indices. The first index is calculated with respect to period t technology, while the second index is evaluated with respect to period $\mathrm{t}+1$ technology.

The productivity change (M) can be decomposed into technical efficiency change (TEC) and technological change (TC). The first ratio in Equation (1) represents the TEC and the second ratio represents the TC. The technological change captures the improvement or the deterioration in the performance of the best practice decision making unions (DMUs), as financial firms tend to be called in the DEA literature. DMU is a more suitable expression than firm when, for example, a bank is studying the performance of its branches. In parallel, technical efficiency change reflects the convergence towards, or divergence from the best practice frontier by the remaining DMUs.

Data

The data have been collected from the balance sheets of the financial institutions provided by Bankscope. We take into account the consolidated balance sheets with or without unconsolidated comparison and as well as the unconsolidated statements with no consolidated comparison in order to include all the banks but only one time each.

The taxonomy of a bank's variables as inputs and outputs is a matter directly related to its function's description. As a result, a plethora of definitions about variables exists in the relatively literature. We can roughly divide the various definitions into three categories based on the preferred approach: the value added approach, the intermediation approach and the user cost approach. The value added approach considers deposits as outputs. The idea is that funds are collected from depositors and there is competition among DMUs to attract customers. Berger and Humphrey (1992) modified this approach and considered deposits as both outputs and inputs. According to the intermediation approach, only banks' assets are thought as outputs, while deposits are regarded as inputs. The notion of this approach is that DMUs buy and sell funds acting as intermediaries between borrowers and receivers of funds. Finally, the user cost approach defines a variable as output or input oriented according to its contribution to bank revenue. That means that if the financial return on the assets exceeds the opportunity cost of funds, DMU's assets are considered as outputs.

Although no approach can be considered as advanced to the others, the value added method has been chosen for the present study. Therefore, the variables that are defined as outputs are: 1) Total deposits, 2) total customer loans and 3) investments. The variable 'investments' is the sum of equity investments and government securities. On the other hand, as input variables are characterized the followings: 1) Personnel expenses, 2) other operating expenses and 3) total fixed assets. All variables are expressed in millions of euros. Exchange rates are obtained from the International Monetary Fund. Finally, variables are considered as the natural logarithms of their nominal values.

\section{EMPIRICAL RESULTS}

Due to the limited number of observations for each year separately, the period 1996-2002 is considered as a whole. Overall, there are 134 firm-year observations. Analytically, the numbers of observations per year are presented in Table 1. The names of financial institutions that are employed for the calculation of the TFP indices and the year for which data are available are illustrated in Table 2. Table 3 presents the empirical findings for the productivity of the Czech banking industry for the period $1996-2002$. 
Table 1: Number Of Observations Per Year

\begin{tabular}{cc}
\hline Year & Number of Observations \\
\hline 1996 & 7 \\
1997 & 8 \\
1998 & 16 \\
1999 & 17 \\
2000 & 23 \\
2001 & 29 \\
2002 & 34 \\
\hline Total & 134 \\
\hline
\end{tabular}

Table 2: DMUs Per Year

\begin{tabular}{|c|c|c|c|c|c|c|c|}
\hline DMUs & 2002 & 2001 & 2000 & 1999 & 1998 & 1997 & 1996 \\
\hline Bank Austria (CR) a.s. & $\sqrt{ }$ & $\sqrt{ }$ & $\sqrt{ }$ & - & - & - & - \\
\hline Bank Austria Creditanstalt Republic - CAS & $\sqrt{ }$ & $\sqrt{ }$ & - & - & $\sqrt{ }$ & - & - \\
\hline Banka Hana, a.s. - CAS & - & $\sqrt{ }$ & - & - & - & - & - \\
\hline Ceska Exportni Banka - IAS- Export Bank - IAS & $\sqrt{ }$ & $\sqrt{ }$ & $\sqrt{ }$ & $\sqrt{ }$ & $\sqrt{ }$ & - & - \\
\hline Ceska konsolidacni agentura - CAS & $\sqrt{ }$ & $\sqrt{ }$ & $\sqrt{ }$ & - & - & - & - \\
\hline Ceska Narodni Banka- National Bank & $\sqrt{ }$ & $\sqrt{ }$ & $\sqrt{ }$ & $\sqrt{ }$ & $\sqrt{ }$ & $\sqrt{ }$ & - \\
\hline Ceska Sporitelna a.s. - IAS & $\sqrt{ }$ & $\sqrt{ }$ & $\sqrt{ }$ & $\sqrt{ }$ & $\sqrt{ }$ & $\sqrt{ }$ & $\sqrt{ }$ \\
\hline Ceskomoravsk $\alpha$ Hypotecn $v$ Banka a.s. & $\sqrt{ }$ & $\sqrt{ }$ & $\sqrt{ }$ & - & - & - & - \\
\hline Ceskoslovenska Obchodni Banka - CSOB - IAS & $\sqrt{ }$ & $\sqrt{ }$ & $\sqrt{ }$ & $\sqrt{ }$ & $\sqrt{ }$ & $\sqrt{ }$ & $\sqrt{ }$ \\
\hline Citibank a.s. - CAS & $\sqrt{ }$ & $\sqrt{ }$ & $\sqrt{ }$ & $\sqrt{ }$ & $\sqrt{ }$ & $\sqrt{ }$ & $\sqrt{ }$ \\
\hline CMSS as-Ceskomoravska Stavebni Sporitelna as & $\sqrt{ }$ & $\sqrt{ }$ & - & - & - & - & - \\
\hline Coop Banka a.s & $\sqrt{ }$ & $\sqrt{ }$ & - & - & - & - & - \\
\hline Credit Lyonnais Bank Praha & $\sqrt{ }$ & $\sqrt{ }$ & $\sqrt{ }$ & $\sqrt{ }$ & $\sqrt{ }$ & $\sqrt{ }$ & $\sqrt{ }$ \\
\hline Dresdner Bank CZ - CAS & - & - & $\sqrt{ }$ & - & - & - & - \\
\hline eBanka as & - & - & $\sqrt{ }$ & $\sqrt{ }$ & $\sqrt{ }$ & - & - \\
\hline Erste Bank Sparkasse (CR) - IAS & $\sqrt{ }$ & $\sqrt{ }$ & - & - & - & - & - \\
\hline Foresbank, a.s. - CAS & - & - & $\sqrt{ }$ & - & - & - & - \\
\hline GE Capital Bank - CAS & $\sqrt{ }$ & $\sqrt{ }$ & $\sqrt{ }$ & $\sqrt{ }$ & $\sqrt{ }$ & $\sqrt{ }$ & $\sqrt{ }$ \\
\hline HVB Bank Republic AS & $\sqrt{ }$ & - & - & - & - & - & - \\
\hline Hypo stavebni sporitelna as & $\sqrt{ }$ & $\sqrt{ }$ & $\sqrt{ }$ & $\sqrt{ }$ & - & - & - \\
\hline Interbanka a.s. - IAS & $\sqrt{ }$ & $\sqrt{ }$ & - & - & - & - & - \\
\hline Investicni a Postovni Banka AS - IPB - IAS & $\sqrt{ }$ & $\sqrt{ }$ & $\sqrt{ }$ & $\sqrt{ }$ & $\sqrt{ }$ & - & - \\
\hline J\&T Banka as & $\sqrt{ }$ & $\sqrt{ }$ & $\sqrt{ }$ & $\sqrt{ }$ & - & - & - \\
\hline Komercni Banka & $\sqrt{ }$ & $\sqrt{ }$ & $\sqrt{ }$ & $\sqrt{ }$ & $\sqrt{ }$ & $\sqrt{ }$ & $\sqrt{ }$ \\
\hline LB Factoring CZ, as & - & $\sqrt{ }$ & $\sqrt{ }$ & - & - & - & - \\
\hline Leasing Ceske Sporitelny & $\sqrt{ }$ & $\sqrt{ }$ & - & - & - & - & - \\
\hline Moravia Banka A.S & $\sqrt{ }$ & $\sqrt{ }$ & - & - & - & - & - \\
\hline $\begin{array}{l}\text { Moravian Guarantee and Develpoment Bank- } \\
\text { Ceskomoravska Zarucni a Rozvojova Banka a.s. - } \\
\text { IAS }\end{array}$ & $\sqrt{ }$ & $\sqrt{ }$ & $\sqrt{ }$ & $\sqrt{ }$ & $\sqrt{ }$ & - & - \\
\hline Patria Finance & $\sqrt{ }$ & $\sqrt{ }$ & - & - & - & - & - \\
\hline Pragobanka as - CAS & $\sqrt{ }$ & - & - & - & - & - & - \\
\hline Prvni Mestska Banka as - CAS & $\sqrt{ }$ & $\sqrt{ }$ & $\sqrt{ }$ & $\sqrt{ }$ & $\sqrt{ }$ & - & - \\
\hline Raiffeisen stavebnv sporitelna AS & $\sqrt{ }$ & - & - & - & - & - & - \\
\hline Societe Generale Banka & $\sqrt{ }$ & - & - & - & - & - & - \\
\hline Stavebnv sporitelna Ceskı Sporitelny as & $\sqrt{ }$ & - & - & - & - & - & - \\
\hline Union banka a.s. - IAS & $\sqrt{ }$ & $\sqrt{ }$ & $\sqrt{ }$ & $\sqrt{ }$ & $\sqrt{ }$ & - & - \\
\hline Universal Banka, a.s. & $\sqrt{ }$ & - & - & - & - & - & - \\
\hline Volksbank CZ as & $\sqrt{ }$ & $\sqrt{ }$ & $\sqrt{ }$ & - & - & - & - \\
\hline Wóstenrot - stavebni sporitelna AS & $\sqrt{ }$ & $\sqrt{ }$ & $\sqrt{ }$ & $\sqrt{ }$ & $\sqrt{ }$ & - & - \\
\hline Zivnostenska banka, a.s. - IAS & $\sqrt{ }$ & - & - & $\sqrt{ }$ & $\sqrt{ }$ & $\sqrt{ }$ & $\sqrt{ }$ \\
\hline
\end{tabular}

$\sqrt{ } \rightarrow$ Available data; -- $\rightarrow$ Not available data 
Table 3: TFP Change Indices Of The Czech DMUs For The Period 1996-2002

\begin{tabular}{cccc}
\hline Obs. & TEC & TC & TFP \\
\hline 134 & 1.087 & 0.913 & 0.993 \\
\hline
\end{tabular}

The first column of Table 3 shows the number of total year-firm observations. The second column indicates the index for the technical efficiency changes (TEC). When TEC is greater than one, this implies that financial institutions have achieved a shift in their technical efficiency during the period 1996 - 2002. If TEC is less than one, financial institutions have experience a decline in their technical efficiency. The third column indicates the technological change (TC) of institutions. This implies that an index greater than one means an improvement in technological performance. Antithetically, whether the TC value is less than unity technological change has met deterioration. The product of TEC and TC provides the total factor productivity (TFP) change index. As long as the value of TFP is greater than unity an improvement in total productivity has taken place. Again, a figure of TFP less than one implies that TFP has been worsened.

The geometric mean of TEC for the 134 DMUs is 1.087. This means that the performance of banks as long as the technical efficiency is concerned experienced an increase of $8.7 \%$. On the other hand, the TC index is lower than unity, specifically 0.913 . The amount of this imperfection is $-8.7 \%$. The total factor of productivity (TFP) change is less than unity (0.993). The value of 0.993 involves an overall slight deterioration of productivity of the Czech banking industry by $0.7 \%$.

Of course, the figure of the productivity decline is pretty close to zero $(-0.7 \%)$, but we have to keep in mind that it refers to the period just before the entrance of the country into the European Union. Hence, after the year 2004 in which the Czech Republic became a full member of the European Union, the financial institutions of the country have to perform into a more competitive global market. That means that DMUs have to undertake all the necessary decisions in order to assure their survival and growth.

\section{SUMMARY}

In this paper we investigated the productivity of the Czech banking industry during the 1996- 2002. Employing the data envelopment analysis (DEA) method and using the value added approach (an output-oriented approach) we calculated the geometric mean for the technological change and the technical efficiency change that occurred during these seven years. We found that the total productivity (measured by the product of technical efficiency change and technological change) deteriorated during the period $1996-2002$ for the Czech banks. More specifically, the total factor of productivity change is less than unity (0.993), implying an overall deterioration of $0.7 \%$ during these years. Moreover, the technical efficiency change (TEC) index is greater than the technological change (TC) index. This implies that the decline of the total productivity is limited only to $-0.7 \%$, rather due to the performance of the remaining DMUs than the performance of the best practice DMUs.

When more data become available, the same measurements should be repeated for a period afterwards 2004, to investigate the trend of Czech DMUs following the entry of the country into The European union. However, in the meantime, the banks' managers and policy makers should be warned and should take precautionary and corrective measures to prevent a repetition of this phenomenon and to recognise the banking industry according to the needs of the new era, in order to survive and become successful in a global and competitive market.

\section{REFERENCES}

1. Arcelus F. J., Arozena P. Measuring Sectoral Productivity across Time an across Countries // European Journal of Operational Research, 1999. 119 (2) - pp. 254-266.

2. Berg S. A., Førrsund F., Jansen E. Malmquist Indices of Productivity Growth during the Deregulation of Norwegian banking 1980-89 // Scandinavian Journal of Economics Supplement, 1994.- pp. 211-228.

3. Berger A. and Humphrey D. Measurement and Efficiency Issues in Commercial Banking // University of Chicago Press, 1992. 
4. Caceres J. Efficiency and Productivity in the Chilean Banking Industry // Working Paper, 2002. Tinbergen Institute

4. Caves D., Christensen L., and Diewert W. The economic theory of index numbers and the measurement of input, output and productivity // Econometrica, 1982 - 50(6) - pp.1393-1414.

5. Charnes A., Cooper W. and Rhodes E. Measuring the efficiency of decision making units // European Journal of Operational Research, 1978. -2- pp. 429-444.

6. Darrat A., Topuz C., and Yousef T. Assessing Cost and Technical Efficiency of Banks in Kuwait', ERF's $8^{\text {th }}$ Annual Conference in Cairo, January 2002

7. Dietsch M. The Efficiency of French Banking Industry // Managerial Finance, 1997. - 23 (1). - pp. 48-56.

8. Elyasiani E. and Mehdian S. The comparative efficiency performance of small and large US commercial banks in the pre and post deregulation eras // Applied Economics, 1995. - 27. -pp. 1069-1079.

9. Fare R., Grosskopf S., Norris M., and Z. Zhang. Productivity growth, Technical Progress, and Efficiency Change in Industrial Countries // American Economic Review, 1994. - 84 (1). -pp. 66-83.

10. Favero C. and L. Papi. Technical efficiency and scale efficiency in the Italian banking sector: a nonparametric approach // Applied Economics, 1995. - 27. -pp. 385-395.

11. Fernández A. I., Gascón F., and González E. Economic Efficiency and Value Maximization in Banking Firms $/ / 7^{\text {th }}$ European Workshop on Efficiency and Productivity Analysis (7EWEPA), Oviedo September 2001.

12. Fukuyama H. Measuring efficiency and productivity growth in Japanese banking: a nonparametric frontier approach // Applied Financial Economics, 1995. - 5. pp. 95-107.

13. Glass J. C., and McKillop D. G. Efficiency in Irish banking: theory and evidence // Applied Financial Economics, 1991. - 1. pp. 235-240.

14. Jackson P., Fethi M. D., and Inal G. Efficiency and Productivity Growth in Turkish Commercial Banking Sector: A non-parametric approach // European Symposium on Data Envelopment Analysis', Wernigerode, Germany, 16-18 October, 1998

15. Malmquist S. Index numbers and indifference surfaces // Trabajos de Estadistica, 1953. - 4. -pp. 209-242.

16. Miller S. and Noulas A. The technical efficiency of large banks production // Journal of Banking and Finance, 1996. -20. - pp. 495-509.

17. Mörttinen L. Banking sector output and labor productivity in six European countries //Bank of Finland discussion papers, 2002. -12

18. Noulas A. Productivity growth in the Hellenic banking industry: state versus private banks // Applied Financial Economics, 1997. - 7. -pp. 223-228.

19. Reddy A. Banking Sector Deregulation and Productivity Change Decomposition of Indian Banks // Working Paper, 2004.

20. Tavares G. A bibliography of Data Envelopment Analysis // Rutcor Research Report, January 2002.

21. Tortosa-Ausina E., Grifell-Tatjě E., and Armero C., D. Conesa. Sensitivity analysis of efficiency and Malmquist productivity indeces: An application to Spanish savings banks // Centre for Applied Economic Research, Working Paper, 2002.

22. Worthington A. Technical Efficiency and Technological Change in Australian Building Societies, 1993/941996/97 // Workshop on Research into Financial Institutions, Centre for Australian Financial Institutions (CAFI), Brisbane 12/13 November 1998. 


\section{NOTES}

